\title{
Bacteriological analysis of blood samples collected from goats in altered behavior
}

\author{
Misha Jawaid ${ }^{1}$, Naseem Ahmad ${ }^{2}$, Zubia Masood ${ }^{3 *}$ and Naheed Afshan ${ }^{4}$ \\ 1. Department of Zoology, Jinnah University for Women, Karachi-Pakistan \\ 2. Department of Pathology, Dow Medical College, Karachi-Pakistan \\ 3. Department of Zoology, Sardar Bhadur Khan Women's University, Balochistan-Pakistan \\ 4. Department of Microbiology, Jinnah University for Women, Karachi-Pakistan \\ *Corresponding author's email: zubiamasood12@gmail.com
}

\section{Citation}

Misha Jawaid, Naseem Ahmad, Zubia Masood and Naheed Afshan. Bacteriological analysis of blood samples collected from goats in altered behavior. Pure and Applied Biology. Vol. 9, Issue 2, pp1460-1472. http://dx.doi.org/10.19045/bspab.2020.90151

Received: 18/11/2019 Revised: 07/02/2020

Accepted: 06/03/2020

Online First: 10/03/2020

\section{Abstract}

Present investigation was based on isolation and identification of bacterial isolates occurs in blood samples taken from 50 healthy and 50 unhealthy goats during the period from February 2017 to January 2018. A total of 100 blood samples were taken from goats to find out their bacterial burden. Out of these samples, 45 samples of unhealthy goats were found to be infected by several harmful bacteria, which reveals their prevalence as, Enterobacter aerogenes (6.6\%), Escherichia coli (8.8\%), Streptococcus bovis (8.8\%), Klebsiella pneomoniae (11.1\%), Cornyebacterium pseudotuberclosis (11.1\%), Streptococcus agalactiae (11.1\%), Listeria monocytogenes (13.3\%), Staphylococcus epidermidis (13.3\%), Staphylococcus aureus (15.5\%). These bacterial pathogens may particularly cause harmful infections, which could be responsible for economic losses in goat farms, reduction of milk and meat productions enterprises. Therefore, our present work would be helpful in prevention and control of certain diseases that could be transmitted to human by milk and meat products. Moreover, as goat is also an indispensable source of income, therefore our present information may also enable the farmers to become more attractive in goat breeding and enable them in rising yield levels. Furthermore, in many countries, goat blood samples are more readily accessible than the other ruminants, thence have also been used an alternative source of blood for the usage in bacteriological culture media. Our present work is one of very few studies that had investigated the bacteriological analysis of blood samples of goats, and would be helpful for assessing their effects on goat health as well as its consumer's health.

Keywords: Blood samples; Goat diseases; Pathogenic bacteria

\section{Introduction}

The term "behavior" can be defined as the whole activities, which the organism shows in response to certain external and internal stimuli received from its environment. In fact, it is the response of any individual or group or species according to its environmental conditions. It's also helps the organism in finding food, water, shelter, mates, as well as in avoiding certain unfavorable environmental conditions i.e., protection from enemies, food scarcity, floods, fires etc. Therefore, now behavior can be classified into three major categories e.g., learned, inherit and social behaviors. Hence, behavior is a very essential criterion in 
assessing the animal health or well-being [1]. Though animal behavior also varies greatly among different domesticated species of livestock; however, for the goat, temperature, daylight, land use, type of vegetation and season, breeds, stage of production, herd size, place for water, types of supplemental feedstuffs, and properties of diets provide in farms have been found the main factors that are influencing mostly on feeding and reproductive behaviors of goats in management practices [2-6]. Therefore, Knowledge about these behaviors is quiet essential for raising the productivity of domesticated animals that are cultured as well as for enhancing the animal welfare of animals. As these domesticated animals are selected for the sake of profitable production of milk, meat and various other food products usually exhibited different behavior than their ancestors. Nowadays, most farmed animals are placed in captivity under more comfortable environments controlled by humans [7-11]. As goat is one of the widespread species of domesticated animals that can be raised in many altered environments in almost every parts of the world, because of its ability to adapt them in highly varied ecological regions and climate conditions. Therefore, all information related to raising goats and their behavior is essential to ensure their better health care, diets and environment conditions. Hence, knowledge and understanding of goat behavior would also be helpful to raise yield levels, which would provide more income to farmers, milk and meats production for consumers; thus, decreasing the stress on animal and its producer [12-14]. The common signs and symptoms regarding to goat health status is essential to be familiar for evaluating that whether goat is healthy or unhealthy, and could also be helpful to recognize clinical signs of certain diseases that are most common in goats. Therefore, farmers should have ability to assess the goat health on a regular basis including, e.g., normal body condition, coat, and vital signs and symptoms of diseases caused by certain pathogens. In healthy status, a normal body temperature of goats is ranged from $101.5^{\circ} \mathrm{F}$ and $103.5^{\circ} \mathrm{F}$, and respiration rate is about 12 to 15 breaths per minute depends upon on environmental temperature, heart rate is 70 and 80 beats/minute, show healthy hair coat, eating and drinking normally, bright eyes with pink eye membrane are good indications of overall health. Whereas, the unhealthy goat shows signs of abnormal eating habits, loss of appetite, depression, diarrhea, abnormal feces and discolored urine, swellings of certain body parts, dull eyes, running nose, abnormal feeding and reproductive behaviors [15].

Bacteria are the smallest creatures of the earth belonging to the prokaryotic family with different morphologies ranging from few micrometers in length [16]. Mostly they are found in the normal flora of gut and skin. Though majority of them are beneficial, but very few have shown harmful in their impacts and produce certain pathogenic diseases [17]. The bacteria can be identified by gram staining as, gram positive and gram negative bacteria [18]. The gram positive bacteria contain thick peptidoglycan layer, and purple when stain, while the gram negative bacteria contain the thin layer of peptidoglycan, and pink when stain [19]. Some pathogenic bacteria that are found in goats includes i.e., Brucella is small sized coccobacilli, gram negative bacteria belongs to the phylum Proteobacteria [20]. Corynebacterium is a genus belonging to the phylum Actinobacteria, which are gram positive nonspore forming rod shaped bacteria, which in some phases of life appears as club shaped [21]. Enterococcus is a gram positive large genus of lactic acid bacteria belonging to phylum Firmicutes, which appearing in pairs (diplococcus) or small chains [22]. 
Escherichia is a genus of gram negative, facultative anaerobic rod shaped bacteria belongs to the family Enterobacteriaceae [23]. In animals, especially in goats, Escherichia coli serotype O157:H7 caused the serious illness that may cause death [24]. Listeria belongs to phylum Firmicutes is a gram positive, non-spore producing, and facultative anaerobic bacteria [25]. Listeria ivanovii and Listeria monocytogenes are specifically affecting goats and can cause non-bloody diarrhea, dehydration, vomiting, and low grade fever [26]. Streptococcus is a genus of gram positive bacteria belongs to Phylum Firmicutes, which is differing from Staphylococcus because of it appearance in chains [22]. Further investigation on bacteriological analysis of goats and other ruminants have been done by [27-32].

Bacterial diseases that are commonly occurs in goats including e.g., Anthrax is caused by gram positive Bacillus anthracis [33]. Johne's disease (Bovine paratuberculosis) is a chronic, infectious bacterial disease of adult goats and is caused by Mycobacterium paratuberculosis [34], and shows symptoms included thickening of intestinal wall, weight loss gradually and chronic diarrhoea dehydration and severe cachexia [35]. Mastitis occur in cattle is caused by gram positive bacteria, such as, Streptococcus agalactiae [36], but it is also caused by different species of Staphylococcus aureus, Streptococcus dysgalactiae, Streptococcus uberis, and Corynebacterium bovis [37]. Symptoms include reduction in milk production, eyes narrowed to slits [38]. Brucellosis is caused by its species includes i.e., Brucella melitensis, Brucella ovis, Brucella abortus, Brucella suis, Brucella neotomae, Brucella ovis and Brucella canis [39], and shows the symptoms that are fever, night sweats, weakness, and hygromas on the knee joint [40]. Listeriosis is caused by Listeria monocytogenes and Listeria ivanovii belongs to genus Listeria, which is a gram positive, anaerobic rod shaped bacteria that cause the severe infections in domestic animals $[41,42]$. Caseous lymphadenitis is caused by the Corynebacterium pseudotuberculosis is very difficult to control due its chronic features [43], and forms the abscesses in lymph nodes internally and externally [44]. Tetanus is also a chronic disease, which is caused by the toxins of Clostridium tetani [45], and its symptoms includes, e.g., lock jaw, stiffness, head high and lameness [46]. Enterotoxaemia (Pulpy kidney) is a fatal disease in goats, which is caused by Clostridium perfringens and diagnosis by diarrhoea, involuntary contraction of body muscles, paralysis and sudden death. Malignant edema is a bacterial disease of goats is caused by Clostridium septicum and is manifested by deep wound infection with trauma, which provides ideal condition for its growth [27]. Moreover, tuberculosis, listeriosis, salmonellosis, toxoplasmosis, brucellosis, as well as streptococcal, staphylococcal and campylobacter infections are examples of some bacterial diseases that have been reported in raw milk and can be transmitted to humans. Prevalence of mastitis agents found in goats includes, Staphylococcus aureus, Streptococcus agalactiae, Escherichia coli and Pseudomonas species have also been isolated from goat milk. Therefore, all such bacterial diseases are now wide-spread throughout the world and consumers that used raw milk are still in facing the risk of food poisoning [47-50]. More recently, new technologies have been developed for the analysis of the complex bacterial diseases found in various body parts of host. Further, due to the profound analysis and comparison of all available information, the whole mechanisms that are contributing in harmful impacts on host health can be well-understood, and new strategies could be made to make sure that all these harms caused 
by bacterial pathogen's is almost negligible $[29,51]$.

As both goat milk and meat are popular amongst the health aware consumers, as well as in certain ethnic groups, therefore, in order to support and increase small-scale meat and dairy products enterprises, various schemes are required to developed for increasing the investments in goat raise farms and also promote small-scale dairy product industries. Likewise, In order to determine the qualities of raw milk and meat produced by smallholder goat farms, a farm-based research studies are essential for extensive production system that would be adequate for the production of safe raw goat milk and meat [52]. As overcrowding, poor housing conditions, transportation and environmental changes stress, improper management, chronic infections, and many other stressful conditions may increase more susceptibility of goats to attain several bacterial diseases. Therefore by keeping in view about the significance of goat as an animated source of both milk and meat products for human consumption, the present study was conducted with based on identification of the different bacteria found in blood samples collected from healthy and unhealthy goats that could be responsible for producing the several harmful impacts on health of goats.

\section{Materials and methods}

Samples of blood were collected from the jugular vein of 100 goats in which 50 goats were healthy and 50 goats were unhealthy. Two tubes were used for the collection, vented and non-vented for the aerobic and anaerobic organisms respectively. About 5 $\mathrm{ml}$ of blood were collected in each with anticoagulant to prevent the samples from clotting. EDTA (ethylenediamine tetra acetic acid) was used as an anticoagulant (Fig. $1 \& 2$ ). The samples were cultured on their selective and differential media including i.e., MacConkey agar, Blood agar and Mannitol salt agar for isolation of microorganisms. The samples were incubated at $37^{\circ} \mathrm{C}$. Gram staining was performed for the detection of gram positive and gram negative bacteria. Gram negative bacteria were introduced to TSI (Triple Sugar Iron Agar) and Citrate test for the confirmation. Culture were inserted in the TSI and Citrate tubes through the needle or wire loop and then placed it for incubation at $37^{\circ} \mathrm{C}$ for 24 hours by following the methods of [32, 53-55].
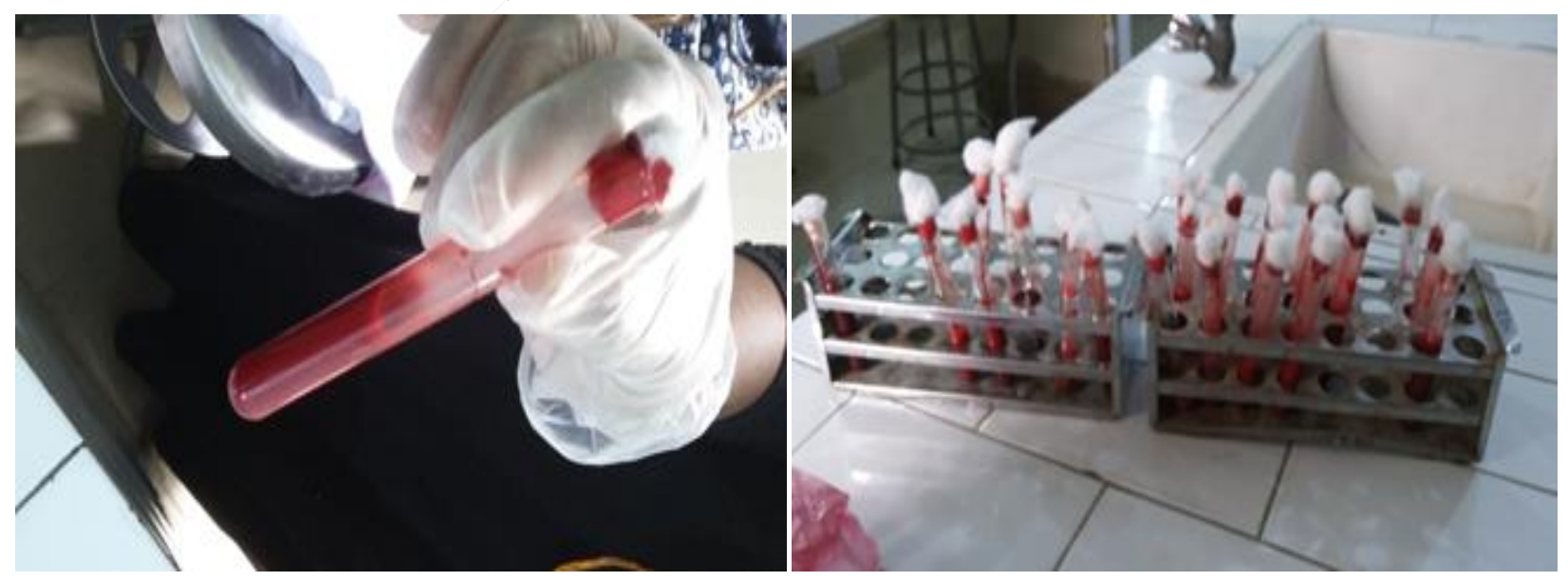

Figure 1. Blood samples of goats 


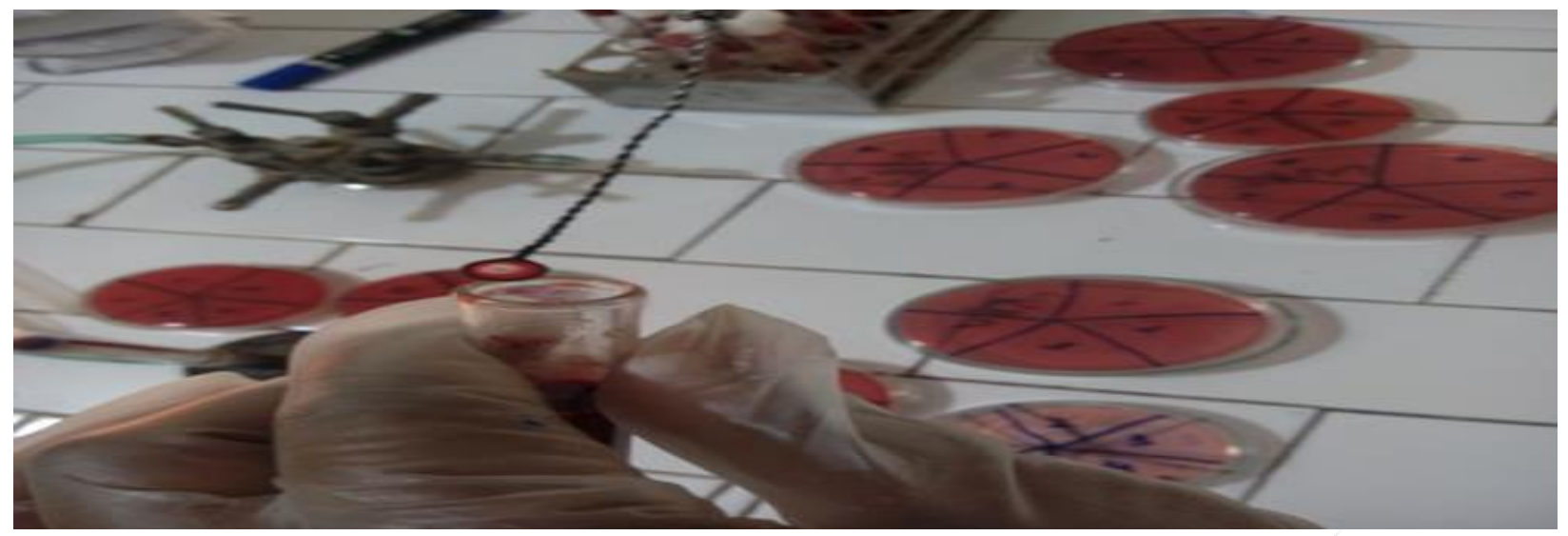

Figure 2. Isolation of blood sample by loopful method

\section{Results and discussion}

Out of 100 blood samples, 45 samples of unhealthy goats were found to be affected by the bacteria. Several pathogenic bacteria were isolated and identified from blood samples of goats of this study that includes, Enterobacter aerogenes (6.6\%), Escherichia coli (8.8\%), Streptococcus bovis (8.8\%), Klebsiella pneomoniae (11.1\%), Cornyebacterium pseudotuberclosis (11.1\%), Streptococcus agalactiae (11.1\%), Listeria monocytogenes (13.3\%), Staphylococcus epidermidis (13.3\%), and Staphylococcus aureus (15.5\%). The overall results revealed that the prevalence of
Enterobacter aerogenes were low, while Staphylococcus aureus were showing their highest rate of contamination in blood. It means Staphylococcus aureus was the main caprine mastitis agent of producing clinical mastitis in goats as reported by [56]. Furthermore, Staphylococcus aureus is the worldwide predominant food poisoning agent of goat milk that may cause the staphylococcal food poisoning in consumers, because many traditional milk products are mostly not exposed for pasteurization in accordance with [57], as shown in (Table 1 and Fig. 3 \& 4).

Table 1. Shows number of goats effected by bacteria, and their percentage in blood samples of goats

\begin{tabular}{|c|c|c|}
\hline $\begin{array}{c}\text { Pathogenic bacteria found from blood } \\
\text { samples }\end{array}$ & $\begin{array}{c}\text { Number of Goats effected by } \\
\text { bacteria }\end{array}$ & Percent (\%) \\
\hline Enterobacter aerogenes & 3 & $* 6.6 \%$ \\
\hline Klebsiella pneomoniae & 5 & $11.1 \%$ \\
\hline Escherichia coli & 4 & $8.8 \%$ \\
\hline Streptococcus bovis & 4 & $8.8 \%$ \\
\hline Staphylococcus aureus & 7 & $* * 15.5 \%$ \\
\hline Staphylococcus epidermidis & 6 & $13.3 \%$ \\
\hline Listeria monocytogenes & 5 & $11.1 \%$ \\
\hline Streptococcus agaalctiae & 5 & $11.1 \%$ \\
\hline Cornyebacterium pseudotuberclosis & 5 \\
\hline \multicolumn{2}{|c|}{ Note: $*$ shows lowest percentage; ** shows highest percentage } \\
\hline
\end{tabular}




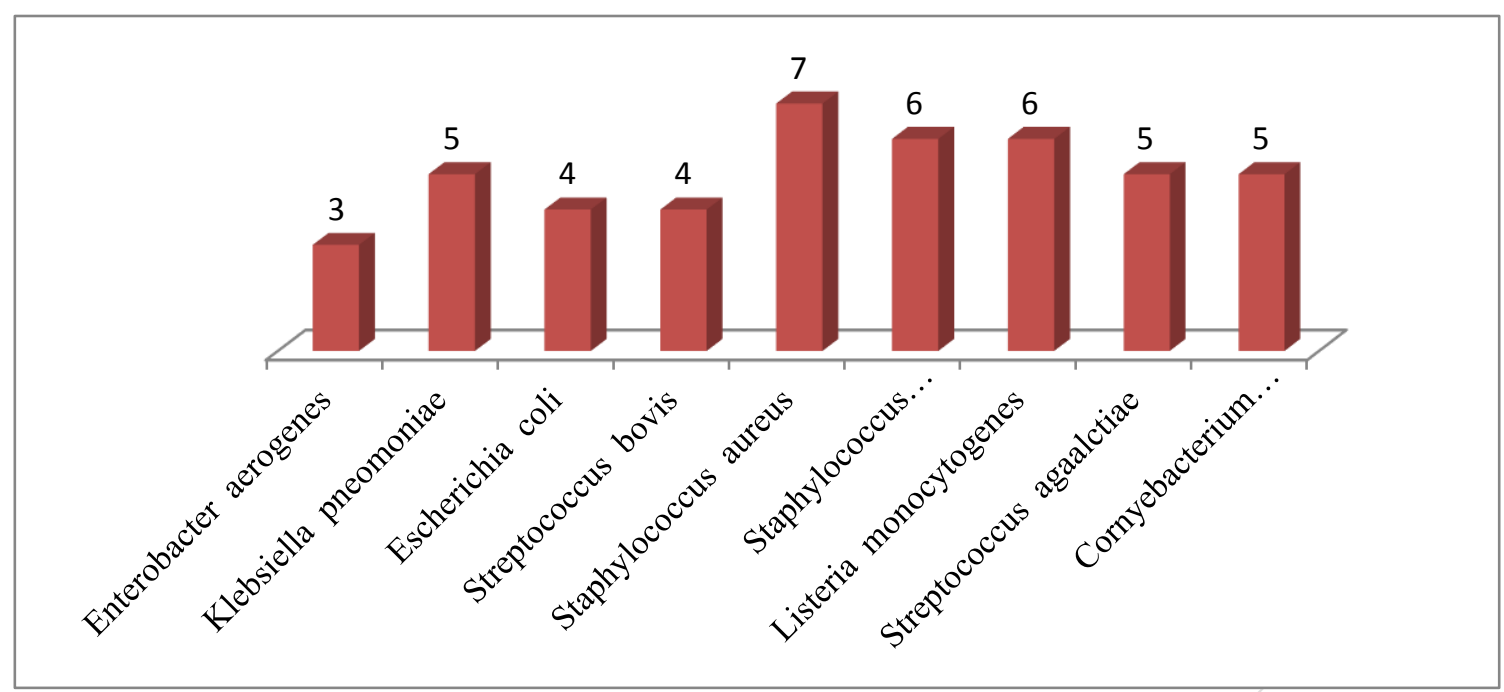

Figure 3. Number of goats effected by bacteria

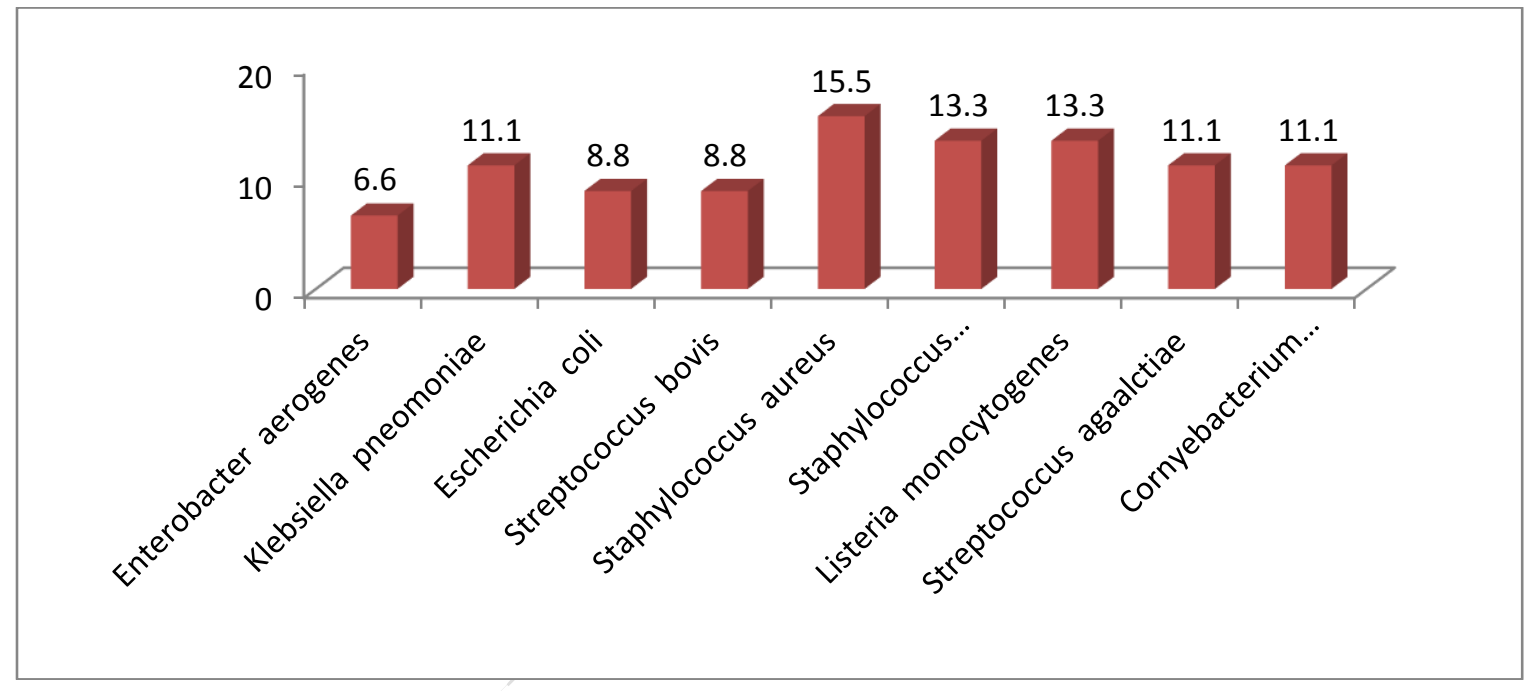

Figure 4. Percentage of bacteria that effects the goats

Streptococcus agalactiae is major cause of intramammary infection that causes the serious infection due to which both meat and milk production decreases. Modern techniques, such as, selective media method can be used for the detection of Streptococcus agalactiae from mill and blood samples in accordance to [36]. The present study shows the presence of Listeria monocytoges isolated from the blood samples of the goat by detecting method, which can cause the serious illness known as listeriosis that may results into death, and also responsible for the transmission to other animals by their fecal materials, as it is excreted out with feces and that contaminated the soil in accordance with [58]. In the present study, there is no finding of Enterotoxaemia, which another disease is caused by the Clostridium perfringes that is responsible for the severe illness in goats, and is commonly found in goats and detected by the PCR analysis and streaking on agar plates. Diarrhea is a common sign of this disease, which is mostly prevalence in North America as reported by [59]. Brucellosis is another main disease occurs in goats caused 
by the Brucella melintensis and Brucella abortus, which also shows the different strains, and highly pathogenic that causes serious illness like abortion in goats in accordance with [60]. The present study shows the presence of causative agent of mastitis i.e., Staphylococcus aureus is also isolated from the blood sample of goat which the main source of economic losses in Pakistan due to the reduction in goat milk. The rate of neutrophils become high in mastitis as compare to the healthy goats and increases death risk if not diagnosis earlier as reported by [61]. Tetanus is commonly found in Pakistan and is considered as a contagious disease caused by the Clostridium tetani, which show different signs, such as, reduction in urination that is predominantly occur in goats. It is a severe disease, which may leads to death of animal if not cured. It is also common in calves by transmitting of the bacteria from mother to young ones during pregnancy. It may be control by the diagnostic programs in accordance with [45]. Johne's disease is also occurs in high rate can cause serious illness of goats, which is caused by the Mycobacterium avium was not reported in the present study. It's detection from serum is more effective than the fecal materials in accordance with [34], as shown in (Tables 2-5, Fig. 5-8) respectively.

Table 2. Bacteria that identified from the blood samples, their origin and diseases caused by them

\begin{tabular}{|c|c|c|}
\hline $\begin{array}{c}\text { Pathogenic bacteria found from } \\
\text { blood sample }\end{array}$ & $\begin{array}{c}\text { Part of the body of goat in } \\
\text { which bacteria effects }\end{array}$ & Diseases caused by bacteria \\
\hline Enterobacter aerogenes & Urinary tract, intestinal tract & Urinary tract infection \\
\hline Klebsiella pneomoniae & Lungs & Pneumonia \\
\hline Escherichia coli & Intestinal tract & $\begin{array}{c}\text { Diarrhea, Infection of the } \\
\text { urinary tract, Pneumonia, } \\
\text { Respiratory illness }\end{array}$ \\
\hline Streptococcus bovis & Alimentary tract & Ruminal acidosis \\
\hline Staphylococcus aureus & Skin, gastrointestinal tract & $\begin{array}{c}\text { Bacteremia, Respiratory } \\
\text { infections, Intramammay } \\
\text { infections. }\end{array}$ \\
\hline Staphylococcus epidermidis & Mammary gland & Mastitis \\
\hline Listeria monocytogenes & Gastrointestinal tract & Listeriosis, Encephalitis \\
\hline Streptococcus agalactiae & Mammary gland, udder & Mastitis \\
\hline Cornyebacterium pseudotuberclosis & Lymph nodes & Caseous lymphadenitis \\
\hline
\end{tabular}

Table 3. Morphology of pathogenic bacteria

\begin{tabular}{|c|c|c|c|c|}
\hline Pathogenic bacteria & $\begin{array}{c}\text { Gram } \\
\text { reaction }\end{array}$ & Shape & Spore formation & Aerobes \\
\hline Enterobacter aerogenes & Negative & Rods in filaments & Non spore forming & Facultative \\
\hline Klebsiella pneomoniae & Negative & Rods in filaments & Non spore forming & Facultative \\
\hline Escherichia coli & Negative & Rods in filaments & Non spore forming & Facultative \\
\hline Streptococcus bovis & Positive & Cocci in chains & Non spore forming & Facultative \\
\hline Staphylococcus aureus & Positive & Cocci in clusters & Non spore forming & Facultative \\
\hline Staphylococcus epidermidis & Positive & Cocci in clusters & Non spore forming & Facultative \\
\hline Listeria monocytogenes & Positive & Rods & Non spore forming & Facultative \\
\hline Streptococcus agalactiae & Positive & Cocci in chains & Non spore forming & Facultative \\
\hline $\begin{array}{c}\text { Cornyebacterium } \\
\text { pseudotuberclosis }\end{array}$ & Positive & Rods & spore forming & aerobes \\
\hline
\end{tabular}


Table 4. Growth characteristics of bacteria on MacConkey agar, Blood agar and MSA

\begin{tabular}{|c|c|c|c|}
\hline Pathogenic bacteria & MacConkey agar & Blood agar & Mannitol salt agar (MSA) \\
\hline Enterobacter aerogenes & Lactose ferment & Gamma hemolysis & No growth \\
\hline Klebsiella pneomoniae & Lactose ferment & Beta hemolysis & No growth \\
\hline Escherichia coli & Lactose ferment & Alpha hemolysis & No growth \\
\hline Streptococcus bovis & Lactose non-ferment & Gamma hemolysis & No growth \\
\hline Staphylococcus aureus & Lactose ferment & Beta hemolysis & No growth \\
\hline $\begin{array}{c}\text { Staphylococcus } \\
\text { epidermidis }\end{array}$ & Non ferment & Gamma hemolysis & No growth \\
\hline Listeria monocytogenes & Lactose non-ferment & Beta hemolysis & No growth \\
\hline Streptococcus agalctiae & Lactose ferment & Beta hemolysis & No growth \\
\hline $\begin{array}{c}\text { Cornyebacterium } \\
\text { pseudotuberclosis }\end{array}$ & Lactose non-ferment & Beta hemolysis & No growth \\
\hline
\end{tabular}

Table 5. Biochemical tests of gram negative bacteria

\begin{tabular}{|c|c|c|c|}
\hline Gram negative bacteria & TSI tube & Citrate tube & Gas production \\
\hline Enterobacter aerogenes & $\begin{array}{c}\text { Lactose fermenter with } \\
\text { acetic acid }\end{array}$ & Positive & Negative \\
\hline Klebsiella pneomoniae & $\begin{array}{c}\text { Lactose fermenter with } \\
\text { acetic acid }\end{array}$ & Positive & Positive \\
\hline Escherichia coli & $\begin{array}{c}\text { Lactose fermenter with } \\
\text { acetic acid }\end{array}$ & Negative & Negative \\
\hline
\end{tabular}

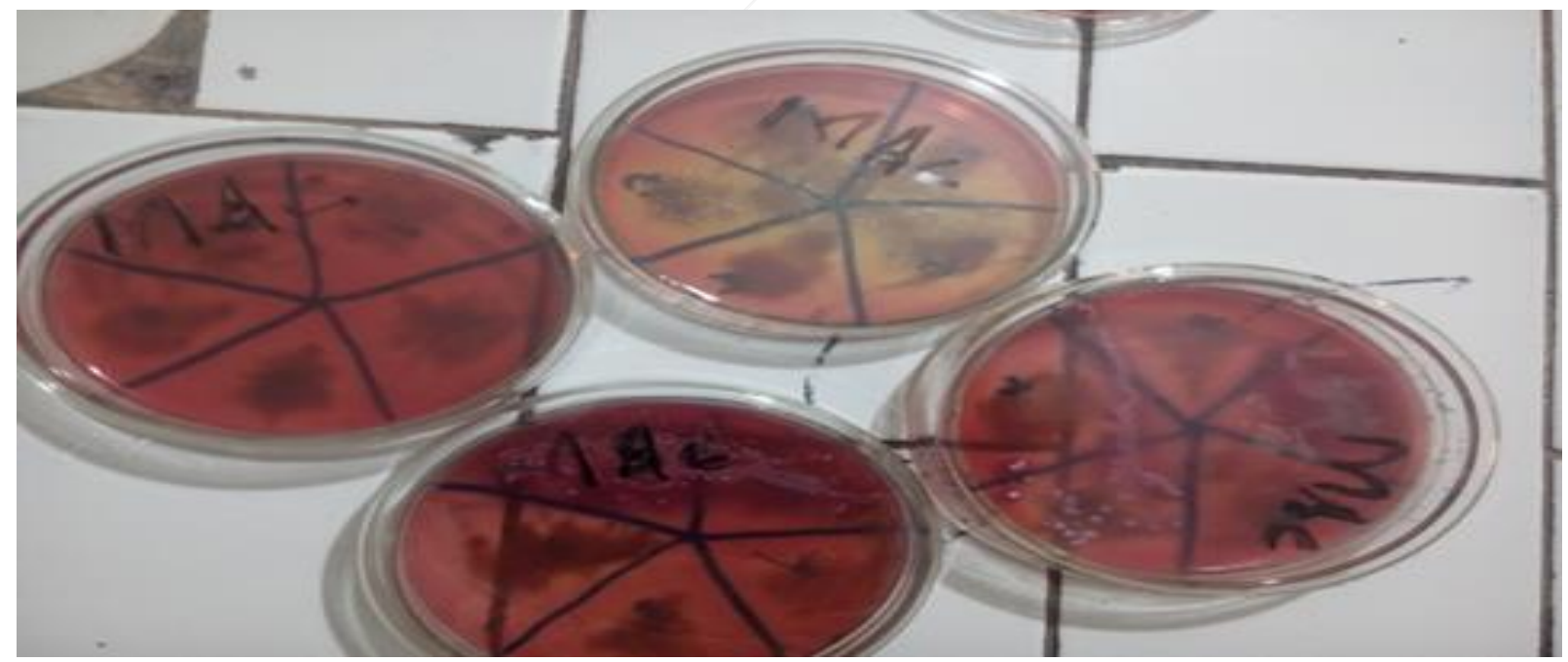

Figure 5. Bactrial growth on MacConkey agar (Pinkcolour indicate the lactose fermenters and Yellow colour indicates the Lactose non-fermenters) 


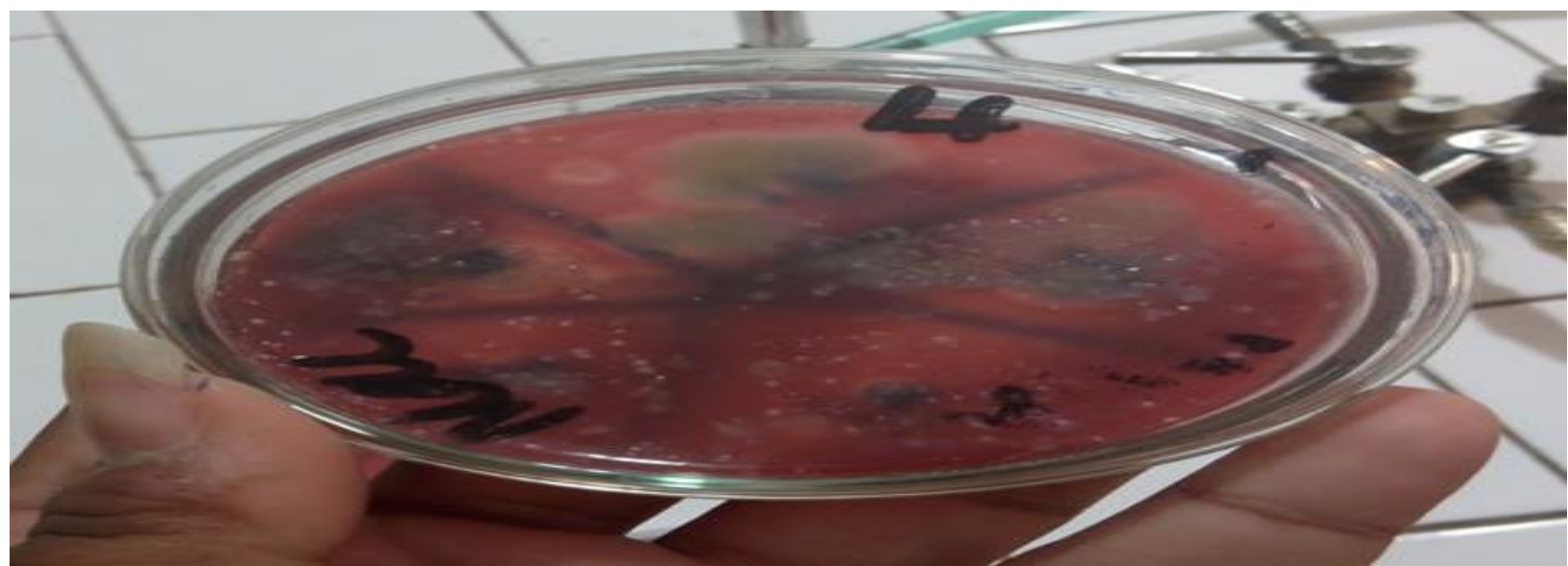

Figure 6. Bacterial growth on Blood agar plates (a) greenish discoloration shows Alpha hemolysis, (b) Colorless shows Beta hemolysis, (c) no change in agar plate shows no hemolysis)

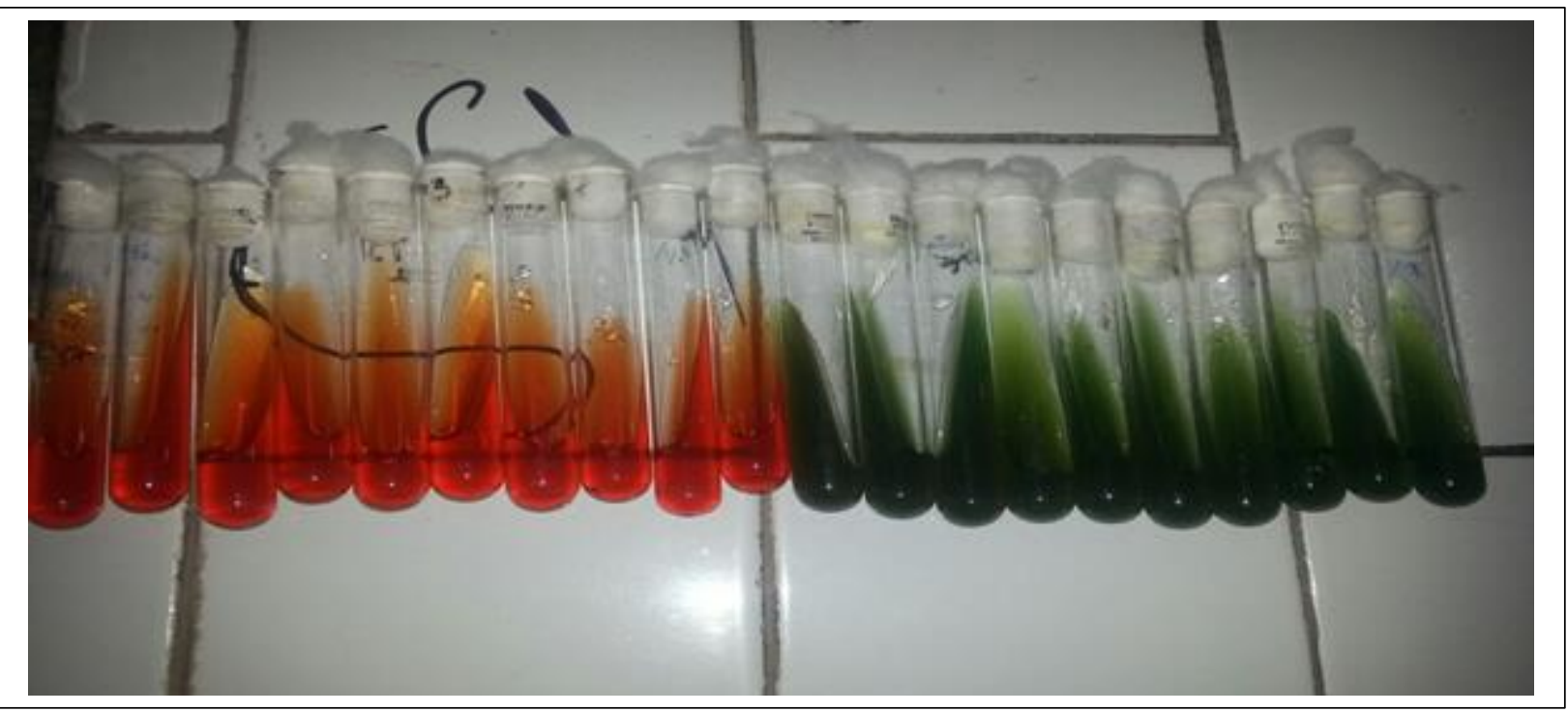

Figure 7. TSI (Orange) and citrate tubes (Green)

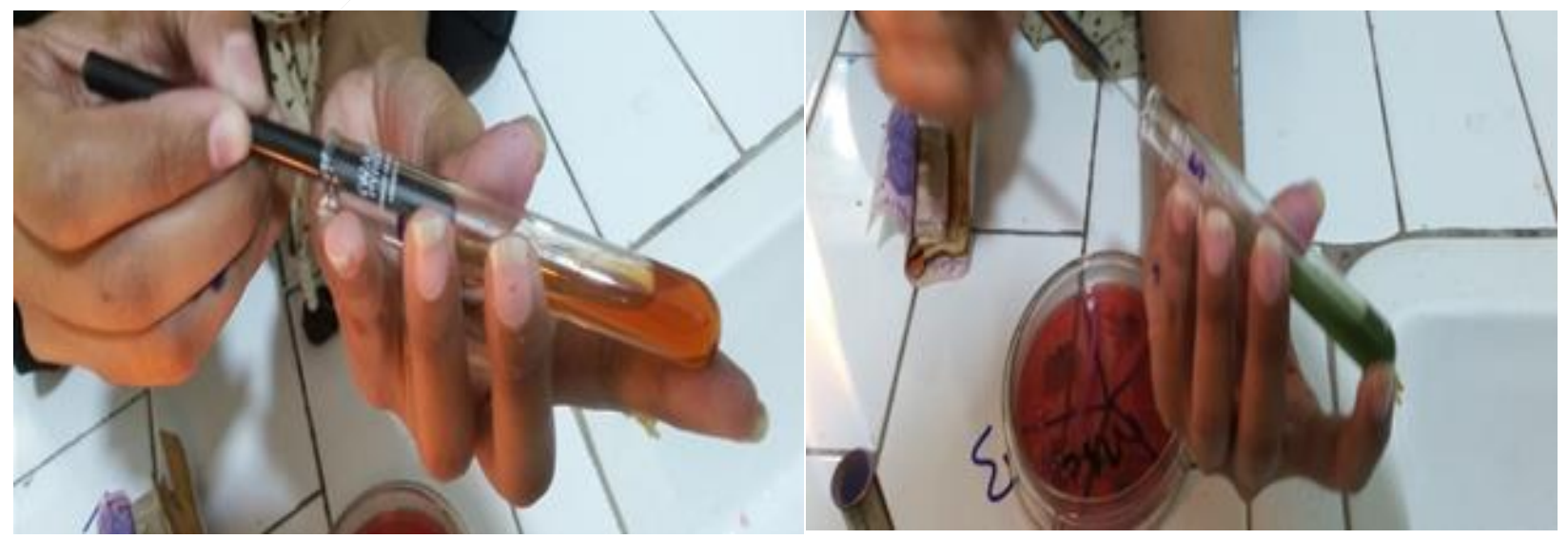

Figure 8. Gram negative bacteria introduce to TSI and Citrate tubes for the confirmation 


\section{Conclusions}

From the present results, it was concluded that goats in Pakistan are suffering from certain pathogenic bacteria that effects on their health and also reduced their meat and milk production, which validating the great economic losses to farmers and industries. They are serving as transmitting vectors that transfers bacterial diseases through their fecal material that contaminated food, soil and water and also to its consumers that used dairy products. Therefore, for the prevention and control of various bacterial diseases, there must be diagnostic programmed should arranged for the diagnosis or examination of goats. Further studies on etiology of these pathogenic bacteria are essential to categorize the main causative agent of goat diseases. Moreover, In many developing countries, due to the high prevalence of certain blood-borne hepatitis pathogens, and lack of satisfactory safety precautions in clinical microbiology laboratory, the goat blood have been most commonly used as bacterial media for the isolation of microorganisms from human tissue and body fluids, as reported by [62-65].

\section{Authors' contributions}

Conceived and designed the experiments: $\mathrm{N}$ Ahmad \& Z Masood, Performed the experiments: $\mathrm{M}$ Jawaid \& $\mathrm{N}$ Afshan, Analyzed the data: M Jawaid, N Ahmad \& Z Masood, Contributed reagents/ materials/ analysis tools: N Afshan, N Ahmad \& Z Masood, Wrote the paper: M Jawaid \& Z Masood.

\section{Acknowledgements}

I express gratitude to Dr. Naseem Ahmed, Dow University of health sciences, Karachi and Ms Naheed Afshan, Jinnah University for Women Karachi for the help in the preparation of bacterial media and identification of bacteria isolates from blood samples of goat during this study.

\section{References}

1. Koluman N, Boga M, Nissim-Silanikove N \& Gorgulu M (2016.) Performance and eating behaviour of crossbred goats in Mediterranean climate of Turkey. $R$ Bras Zootec 45(12): 768-772.

2. Lachica M \& Aguilera JF (2005) Energy needs of the free ranging goat. Small Rumin Res 60: 111-126.

3. Papachristou TG, Platis PD \& Nastis AS (2005). Foraging behaviour of cattle and goats in oak forest stands of varying coppicing age in Northern Greece. Small Rumin Res 59: 181-189.

4. El-Aich A, El Assouli N, Fathi A, MorandFehr P \& Bourbouze A (2007). Ingestive behavior of goats grazing in the southwestern Argan (Argania spinosa) forest of Morocco. Small Rumin Res 70: 248-256.

5. Animut G \& Goetsch AL (2008). Cograzing of sheep and goats: Benefits and constraints. Small Rumin Res 77: 127-145.

6. Goetsch A, Gipson T, Askar A, Puchala R (2010). Invited review: Feeding behavior of goats. J Anim Sci 88: 361-373.

7. Kaymakci M (2002). Üreme Biyolojisi (Reproductive Biology). EÜZF İzmir 503: 305.

8. Kaymakci M (2013). İleri Keçi Yetiştiriciliği (Advanced Goat Breeding). Bornova-İzmir ISBN 978-60585998-0-2.

9. Unal N (2004). Hayvan refahı (Animal Welfare). I. Nat Vet Anim Sci Cong, Elazıg, 347. Turkey.

10. Yakan A, Unal N \& Akcapinar H (2007). Keçilerde Davranış (Behaviour of Goat). Lalahan Hay Araşt Enst Derg 47(1): 39-47.

11. Pambu RG, Webb EC \& Mohale L (2011). Differences in milk yield and composition of different goat breeds rose in the same environment in South Africa. Agric J 6: 237-242.

12. Kilgour R \& Dalton C (1984). Livestock Behaviour. Granada Publishing Ltd, London, pp 90-93. 
13. Haenlein GFW, Caccese R \& Sammelwitz PH (1992). Behavior. Goat Extension Handbook. University of Delaware, Newark, Delaware, pp 1-7.

14. Tuncer SS, Sireli HD \& Tatar AM (2016). Behavioral Patterns of Goats. $7^{\text {th }}$ Int Sci Agri Symp., "Agrosym 2016" 6-9 October 2016, Jahorina, Bosnia and Herzegovina. Faculty of Agriculture, University of East Sarajevo, Bosnia and Herzegovina, pp 2369-2374.

15. Jones J (2007). Keeping Your 4-H Market Animals Healthy (4-H 140). Oregon State University Extension Service, pp 12.

16. Fredrickson JK, Zachara JM, Balkwill DL, Kennedy D, Li SM, Kostandarithes HM, Daly MJ, Romine MF \& Brockman FJ (2004). Geomicrobiology of high-level nuclear waste-contaminated vadose sediments at the Hanford site, Washington State. Appl Environ Microb 70(7): 42304241.

17. Sears CL (2005). A dynamic partnership: celebrating our gut flora. Anaerobe 11(5): 247-51.

18. Demchick P \& Koch AL (1996). The permeability of the wall fabric of Escherichia coli and Bacillus subtilis. J Bacteriol 178(3): 768-773.

19. Ryter A (1988). Contribution of new cryomethods to a better knowledge of bacterial anatomy. Ann Inst Pasteur Mirobiol 139(1): 33-44.

20. Corbel MJ (1997). Brucellosis: an overview. Emerg Infect Dis 3(2): 213-221.

21. Collins MD, Hoyles L, Foster G, Falsen E (2004). Corynebacterium caspium sp. nov., from a Caspian seal (Phocacaspica). Int $J$ Syst Evol Microbiol 54(3): 925-928.

22. Ryan KJ \& Ray CG (2004). Medical microbiology. An introduction to infectious diseases. In: Sherris JC, editor. Sherris Medical Microbiology. Elsevier. New-York (USA), pp 551-552.

23. Madigan MT \& Martinko JM (2005). Brock Biology of Microorganisms. 11th edition.
Prentice Hall, Upper Saddle River, New Jersey, USA, pp 992.

24. Hogan MC (2010). Bacteria. In: Sidney D \& Cleveland CJ, editors. Encyclopedia of Earth. National Council for Science and the Environment, Washington DC.

25. Jamshidi A \& Zeinal $T$ (2019). Significance and Characteristics of Listeria monocytogenes in Poultry Products. Int $J$ Food Sci 1-7.

26. Christelle OJL, Alban LM, Alexandre L, Frédéric M, Marie FMB, Magdalena KB, Mariela S, Olivier D, Patrick B, José VB, Olivier L \& Marc L (2010). Human Listeriosis Caused by Listeria ivanovii. Emerg Infect Dis 16(1): 136-138.

27. Herenda D, Chambers PG, Ettriqui A, Seneviratna P \& da Silva TJP (1994). Manual on meat inspection for developing countries. FAO Animal Production And Health Technical Paper No. 119. Food and Agriculture Organization of the United Nations Rome, Italy, pp 486.

28. Gulcu H \& Ertas H (2004). Bacteriological Investigation of Udder Lobes of Cows with Mastitis Slaughtered in the Elazığ Region. Turk J Vet Anim Sci 28(1): 91-94.

29. Kim HB \& Isaacson RE (2015). The pig gut microbial diversity: understanding the pig gut microbial ecology through the next generation high throughput sequencing. Vet Microbiol 177: 242-251.

30. Malmuthuge N \& Guan LL (2016). Gut microbiome and omics: a new definition to ruminant production and health. Anim Front 6: 8-12.

31. Tarabees R, Elsify A, Mahboub H \& Ballal SE (2016). Multi-drug resistant aerobic bacteria associated with Pneumo-enteritis in small ruminants in three Egyptian provinces a field study. $J$ Vet Sci 51 37-47.

32. Sukanta KS, Mohammed RC, Mahbub EE \& Abu BS (2018). Bacteriological and Histopathological Investigation of Pneumonia in Black Bengal Goat. Dairy and Vet Sci J 6(4): 1-7. 
33. Robert M, Kathleen B, Robert G, Ricardo C, Gene HSL, Jean LP \& George GI (2006). Detection of Anthrax Toxin in the Serum of Animals Infected with Bacillus anthracis by Using Engineered Immunoassays. Clin Vaccine Immunol 13(6): 671-677.

34. Linglingli JP, Bannantine JJC, Arlo R, Yrjo TG, Robab K, Megan S, Jessica R \& Vivek $K$ (2017). Identification of Sero-reactive antigens for the early diagnosis of Johne's disease in cattle. Plos One 12(9): e0184373.

35. Stabel JR (1998). Johne's disease: a hidden threat. J Dairy Sci 81(1): 283-288.

36. Gregory PK (1997). Streptococcus agalactiae mastitis: A review. Can Vet J 38: 429-437.

37. Deb R, Kumar A, Chakraborty S, Verma AK, Tiwari R, Dhama K, Singh U \& Kumar S (2013). Trends in diagnosis and control of bovine mastitis a review. Pak $J$ Biol Sci 16(23): 1653-1661.

38. Hertl JA, Grohn YT, Leach JD, Bar D \& Bennett GJ (2010) Effects of clinical mastitis caused by gram-positive and gramnegative bacteria and other organisms on the probability of conception in New York state Holstein dairy cows. J Dairy Sci 93: 1551-1560.

39. Jacques G, Klaus N \& Claude S (2010). Diagnosis of Brucellosis in Animals. Croat Med J 51: 296-305.

40. Ilhan Z, Aksakal A, Ekin IH, Gülhan T, Solmaz H \& Erdenlig S (2007). Comparison of culture and PCR for the detection of Brucella melitensis in blood and lymphoid tissues of serologically positive and negative slaughtered sheep. Lett Appl Microbiol 46(2008): 301-306.

41. Vázquez-Boland JA, Kuhn M and Berche P, Chakraborty T, Domínguez-Bernal G, Goebel W, González-Zorn B, Wehland J \& Kreft J (2001). Listeria pathogenesis and molecular virulence determinants. Clin Microbiol Rev 14(3): 584-640.

42. Nightingale KK, Schukken YH, Nightingale CR, Fortes ED, Ho AJ, Her Z,
Grohn YT, McDonough PL \& Wiedmann M (2004). Ecology and Transmission of Listeria monocytogenes Infecting Ruminants and in the farm environment. Appl Environ Microbiol 70(8): 4458-4467.

43. Rebouças MF, Portela RW, Lima DD, Loureiro D, Bastos BL, Moura-Costa LF, Vale VL, Miyoshi A, Azevedo V \& Meyer R (2011). Corynebacterium pseudotuberculosis secreted antigeninduced specific gamma-interferon production by peripheral blood leukocytes: potential diagnostic marker for Caseous lymphadenitis in sheep and goats. $J$ Vet Diagn Invest 23(2): 213-220.

44. Williamson LH (2015). Caseous Lymphadenitis in small ruminants. Caseous Lymphadenitis in Small Ruminants. Vet Clin North Am Food Anim Pract 17(2): 359-371.

45. Nuri A, Nazmi Y, Abdullah K, Fatma İ, Ebubekir C, İsmail HE \& Sezai A (2017). Diagnosis and treatment of umbilical cordderived tetanus in neonatal calves. Turk $J$ Vet Anim Sci 41: 317-322.

46. Arsala K, Sayed HAR, Muhammad S, Muhammad AA, Muhammad S, Daryoush B, Imtiaz HRA, Hafiz MZ, Farman A \& Siyal RNS (2016). Diagnosis and Therapeutic Management of Tetanus in Female Buffalo Calf at Tandojam, Sindh, Pakistan. World Vet J 6(2): 66-69.

47. Maisi P \& Riipinen I (1991). Pathogenicity of different species of Staphylococci in caprine udder. Br Vet J 147: 126-132.

48. Mowlem A (1988). Goat farming. Farming Press Ltd. Ipswich, UK, pp 183.

49. Ryan DP \& Greenwood PL (1990). Prevalence of udder bacteria in milk samples from four dairy goat herds. Aust Vet J 67: 362-363.

50. White EC \& Hinckley LS (1999). Prevalence of mastitis pathogens in goat milk. Small Ruminant Res 33: 117-121.

51. Zhou J, He Z, Yang Y, Deng Y, Tringe SG \& Alvarezcohen L (2015). High-throughput 
metagenomic technologies for complex microbial community analysis: open and closed formats. Mbio 6(1): 1-17.

52. Kyozaire JK, Veary CM, Petzer IM \& Donkin EF (2005). Microbiological quality of goat's milk obtained under different production systems. J $S$ Afr Vet Assoc 76(2): 69-73.

53. Vandepitte J, Verhaegen J, Engbaek K, Rohner P, Piot P \& Heuck CC (2003). Basic laboratory procedures in clinical bacteriology. $2^{\text {nd }}$ edition. World Health Organization Geneva 20 Avenue Appia, 1211 Geneva 27, Switzerland, pp 188.

54. Cavalcante MP, Alzamora F, Almeida MGÃR, Silva NS, Barros CGG \& Silva MCA (2013). Bacteria involved in subclinical mastitis in goats in the region of Salvador, Bahia, Brazil. Arq Inst Biol 80(1): 19-26.

55. Mavangira V, Angelos J, Samitz E, Rowe J \& Byrne B (2013). Gangrenous mastitis caused by Bacillus species in six goats. $J$ Am Vet Med Assoc 242(6): 836-843.

56. Bergonier D, De Crémoux R, Rupp R, Lagriffoul G \& Berthelot X (2003). Mastitis of dairy small ruminants. Vet Res34: 689716.

57. Merz A, Stephan R \& Johler S (2016). Staphylococcus aureus Isolates from Goat and Sheep Milk Seem to Be Closely Related and Differ from Isolates Detected from Bovine Milk. Front Microbiol 7(319): 1-7.

58. Ueno H, Yokota K, Arai T, Muramatsu Y, Taniyama H, Iida T \& Morita C (1996). The prevalence of Listeria monocytogenes in the environment of dairy farms. Microbiol Immunol 40: 121-124.

59. Uzal FA \& Kelly WR (1998). Experimental Clostridium perfringens type D enterotoxemia in goats. Vet Pathol 35(2): 132-140.

60. Scholz HC \& Vergnaud G (2013). Molecular characterization of Brucella species. Rev Sci Tech 32: 149-162.

61. Quyyum A, Jawaria A K, Riaz H, Muhammad A, Nisar A \& Sarwar M K (2016). Investigation of Milk and Blood Serum Biochemical Profile as an Indicator of Sub-Clinical Mastitis in Cholistani Cattle. Pak Vet J 36(3): 275-279.

62. Chandar A, Rhonda G, Helene S, Kevin F $\&$ Merle O (2000). Pig and Goat Blood as Substitutes for Sheep Blood in BloodSupplemented Agar Media. J Clin Microbiol 38(2): 591-594.

63. Egwuatu T, Ogunsola F, Okodugha I, Bamiro J, Arewa D \& Osinupebi O (2014). Effect of Blood Agar from Different Animal Blood on Growth Rates and Morphology of Common Pathogenic Bacteria. Adv Microbiol 4: 1237-1241.

64. Jaubert G \& Kalantzopoulos G (1996). Quality of goat milk for cheese and other products. Proc. 6th Int Conf on Goats. International Academic Publishers, Beijing, China, 6-11 May 1996, pp 274-284.

65. Zaman S, Ahad A \& Sarker Md (2018). Isolation and identification of buccal and intestinal bacteria in goats in Chittagong, Bangladesh. Int J Adv Res Biol Sci 5(4): 6471. 